\title{
Hubungan Pola Makan dengan Status Gizi Anak Usia 3-5 tahun di Wilayah Kerja Puskesmas Nanggalo Padang 2014
}

\author{
Gustiva Sari ${ }^{1}$, Gustina Lubis $^{2}$, Edison $^{3}$
}

\begin{abstract}
Abstrak
Status gizi yang buruk merupakan salah satu penyebab kematian pada anak. Jumlah anak dengan status gizi kurang dari tahun 2011 ke tahun 2012 di wilayah kerja Puskesmas Nanggalo mengalami peningkatan. Tujuan penelitian ini adalah menentukan hubungan pola makan dengan status gizi pada anak usia 3-5 tahun di wilayah kerja Puskesmas Nanggalo. Desain penelitian ini adalah cross sectional study dengan pola makan sebagai variabel independen dan status gizi sebagai variabel dependen. Populasi penelitian ini adalah semua anak usia 3-5 tahun yang berdomisili di wilayah kerja Puskesmas Nanggalo. Pengambilan subjek menggunakan teknik simple random sampling yang dibuat secara proporsional. Analisis data menggunakan uji Fisher. Hasil penelitian yang didapatkan $68 \%$ anak dengan pola makan yang baik mempunyai status gizi normal, dan $11 \%$ anak dengan pola makan tidak baik mengalami kekurusan. Hasil uji statistik menunjukkan pola makan mempunyai hubungan dengan status gizi $(p=0,000)$. Dapat disimpulkan bahwa terdapat hubungan yang antara pola makan dengan status gizi. Penerapan pola makan yang baik pada anak maka status gizi anak akan menjadi baik.
\end{abstract}

Kata kunci: pola makan, status gizi, anak usia 3-5 tahun

\begin{abstract}
Malnutrition is one of the cause of childhood deaths. The year of 2011 until 2012, the cases of children with malnutrition in area of Nanggalo Health Center was increased. The objective of this study was to determine the correlation diet on nutritional status in children aged 3-5 years old in area of Nanggalo Health Center. This research used cross-sectional study, the diet as the independent variable and nutritional status as the dependent variable. The population was all of children aged 3-5 years in area of Nanggalo Health Center. Subjects was taken by using simple random sampling technique with proportionally. The data analysis was Fisher test. The results of the study found $68 \%$ of children with a good diet have normal nutritional status, and $11 \%$ of children with a bad diet have a stunting. The Statistic results showed that diet has a relationship on nutritional status $(p=0.000)$.
\end{abstract}

Keywords: diet, nutritional status, children aged 3-5 year old

Affiliasi penulis: 1. Pendidikan Dokter FK UNAND (Fakultas Kedokteran Universitas Andalas Padang), 2. Bagian IImu Kesehatan Anak FK UNAND, 3. Bagian IImu Kesehatan Masyarakat FK UNAND Korespondensi: Gustiva Sari, Email: gustiva.sari@yahoo.com, Telp: 082285164224

\section{PENDAHULUAN}

Indonesia merupakan salah satu negara berkembang yang mempunyai masalah gizi utama berupa masalah gizi kurang. ${ }^{1}$ Berdasarkan indikator berat badan menurut tinggi badan (BB/TB, Z-score), jumlah prevalensi balita sangat kurus dan kurus tahun 2013 di Indonesia sebesar 12,1\%, menurut World Health Organization (WHO) hal ini sudah termasuk masalah kesehatan masyarakat yang serius. ${ }^{2}$

Berdasarkan hasil Riset Kesehatan Dasar (RISKESDAS) 2013, prevalensi balita sangat kurus dan kurus dengan indikator yang sama di Sumatra Barat tahun 2010 sebesar 8,2\%, dan meningkat menjadi $12,5 \%$ pada tahun 2013, angka ini berada diatas angka prevalensi nasional. ${ }^{2}$ Berdasarkan data 
dari Dinas Kesehatan Kota (DKK) Padang tahun 2011, $0,16 \%$ balita dari jumlah seluruh balita di Kota Padang mengalami gizi buruk, dan pada tahun 2012 terjadi peningkatan menjadi $0,24 \%{ }^{3}$

Anak usia 3-5 tahun mempunyai risiko untuk mengalami masalah kekurangan gizi, karena pada masa ini sering terjadi masalah makan yang disebabkan anak sudah mulai menjadi konsumen aktif yang cendrung memilih-milih makanan yang akan dikonsumsi. ${ }^{4}$ Faktor makanan merupakan faktor langsung yang mempengaruhi status gizi. Faktor makanan ini berupa pola makan yang dapat dinilai dari jumlah dan jenis makanan yang dikonsumsi, serta cara pemberian makan. ${ }^{5}$

Berdasarkan latar belakang di atas, maka perlu diteliti hubungan pola makan dengan status gizi pada anak usia 3-5 tahun di wilayah kerja Puskesmas Nanggalo Padang tahun 2014.

\section{METODE}

Penelitian ini menggunakan metode cross sectional dimana pola makan sebagai variabel independen dan status gizi sebagai variabel dependen. Penelitian dilakukan dari Januari sampai Juni 2014. Populasi penelitian ini adalah anak usia 3-5 tahun di wilayah kerja Puskesmas Nanggalo Padang. Sampel adalah bagian dari populasi yang diteliti yang memenuhi kriteria inklusi, pada penelitian ini berjumlah sebanyak 85 orang.

Data primer didapatkan dengan melakukan wawancara langsung kepada orang tua atau pengasuh anak usia 3-5 tahun dengan panduan kuesioner pola makan, serta melakukan penimbangan berat badan (BB) dan pengukuran tinggi badan (TB) langsung pada anak.

Instrumen yang digunakan dalam penelitian ini adalah kuesioner pola makan, grafik pertumbuhan anak 2-5 tahun WHO 2006 (BB/TB, Z-scores), timbangan BB (bathroom scale) dan microtoise. Status gizi dinilai berdasarkan kriteria WHO 2006 (BB/TB, Zscores), yaitu sangat kurus (<-3 SD), kurus (-3 SD s/d $<-2$ SD), normal (-2 SD s/d 2 SD). Pengolahan data dilakukan editing, coding, entry, dan cleaning.
HASIL

\section{Karakteristik Responden}

Berdasarkan tingkat pendidikan 85 responden, lebih dari separuh responden (55,3\%) memiliki tingkat pendidikan sedang. Berdasarkan pekerjaan, sebagian besar responden $(78,8 \%)$ adalah ibu rumah tangga.

Tabel 1. Karakteristik responden

\begin{tabular}{lcc}
\hline \multicolumn{1}{c}{ Variabel } & $\mathbf{f}$ & $\%$ \\
\hline Tingkat Pendidikan & & \\
Rendah & 20 & $23,5 \%$ \\
Sedang & 47 & $55,3 \%$ \\
Tinggi & 18 & $21,2 \%$ \\
\hline Pekerjaan & & \\
IRT & 67 & $78,8 \%$ \\
Pegawai Swasta & 10 & $11,8 \%$ \\
PNS & 8 & $9,4 \%$ \\
\hline
\end{tabular}

Berdasarkan jenis kelamin anak usia 3-5 tahun, 46 orang anak $(54,1 \%)$ adalah laki-laki dan 39 orang anak $(45,9 \%)$ adalah perempuan.

Tabel 2. Distribusi jenis kelamin anak usia 3-5 tahun

\begin{tabular}{lcc}
\hline \multicolumn{1}{c}{ Jenis Kelamin } & f & $\%$ \\
\hline Laki-laki & 46 & $54,1 \%$ \\
Perempuan & 39 & $45,9 \%$ \\
\hline
\end{tabular}

\section{Distribusi Status Gizi Anak Usia 3-5 Tahun}

Berdasarkan status gizi didapatkan bahwa umumnya anak usia 3-5 tahun $(88,2 \%)$ mempunyai status gizi yang normal berdasarkan indeks BB/TB (Zscore).

Tabel 3. Distribusi status gizi anak usia 3-5 tahun

\begin{tabular}{lcc}
\hline \multicolumn{1}{c}{ Variabel } & f & $\%$ \\
\hline Status Gizi & & \\
Sangat Kurus & 5 & $5,9 \%$ \\
Kurus & 5 & $5,9 \%$ \\
Normal & 75 & $88,2 \%$ \\
\hline
\end{tabular}

\section{Distribusi Pola Makan Anak Usia 3-5 Tahun}

Berdasarkan pola makan didapatkan bahwa lebih dari separuh anak usia 3-5 tahun (69,4\%) mempunyai pola makan yang baik. 
Tabel 4. Distribusi pola makan anak usia 3-5 tahun

\begin{tabular}{lcc}
\hline \multicolumn{1}{c}{ Variabel } & f & $\%$ \\
\hline Pola Makan & & \\
Tidak Baik & 26 & $30,6 \%$ \\
baik & 59 & $69,4 \%$ \\
\hline
\end{tabular}

\section{Hubungan Pola Makan dengan Status Gizi}

Tabel 5 dibawah ini menjelaskan hubungan pola makan dengan status gizi.

Tabel 5. Hubungan pola makan dengan status gizi

\begin{tabular}{|c|c|c|c|c|c|}
\hline \multirow{3}{*}{ Variabel } & \multicolumn{4}{|c|}{ Status Gizi } & \multirow{3}{*}{ p } \\
\hline & \multicolumn{2}{|c|}{$\begin{array}{c}\text { Sangat } \\
\text { Kurus+Kurus }\end{array}$} & \multicolumn{2}{|c|}{ Normal } & \\
\hline & $f$ & $\%$ & $f$ & $\%$ & \\
\hline \multicolumn{6}{|l|}{$\begin{array}{l}\text { Pola } \\
\text { Makan }\end{array}$} \\
\hline Tidak Baik & 9 & $34,6 \%$ & 17 & $65,4 \%$ & 0,000 \\
\hline Baik & 1 & $1,7 \%$ & 58 & $98,3 \%$ & \\
\hline Total & 10 & $11,8 \%$ & 75 & $88,2 \%$ & \\
\hline
\end{tabular}

Berdasarkan Tabel 5 dapat dilihat bahwa sebanyak 58 anak usia 3-5 tahun (68,2\%) dengan pola makan yang baik mempunyai status gizi yang normal lebih banyak daripada anak yang mempunyai pola makan yang baik dengan status gizi sangat kurus dan kurus yang berjumlah 1 orang $(1,2 \%)$. Hasil uji statistik dengan uji Fisher menunjukkan adanya hubungan antara pola makan dengan status gizi $(p<0,05)$.

\section{PEMBAHASAN}

\section{Hubungan Pola Makan dengan Status Gizi}

Analisis dengan uji Fisher menunjukkan terdapat hubungan yang signifikan antara pola makan dengan status gizi. Hasil ini sesuai dengan penelitian Waladow et al dengan hasil yang menunjukkan nilai signifikan $\mathrm{p}(0,00)$ yang berarti ada hubungan yang bermakna antara pola makan dengan status gizi. ${ }^{6}$

Pola makan yang baik terdiri dari konsumsi makanan yang berkualitas yaitu konsumsi makanan yang sehat dan bervariasi, serta konsumsi makanan yang cukup dari segi kuantitas diikuti dengan menerapkan perilaku makan yang benar. Jika hal ini diterapkan, makan akan menghasilkan status gizi anak yang normal. ${ }^{7}$

Pada penelitian ini ditemukan (20\%) anak dengan status gizi normal, namun mempunyai pola makan yang tidak baik. Berdasarkan hasil wawancara, cara pemberian makan pada anak-anak ini tidak sesuai dengan yang seharusnya, namun jumlah asupan kalori yang dikonsumsi sesuai dengan angka kecukupan gizi (AKG) nya masing-masing, sehingga menghasilkan status gizi yang normal.

Pada penelitian ini juga ditemukan 1,2\% anak usia 3-5 tahun mempunyai pola makan yang baik, tapi mempunyai status gizi yang sangat kurus. Hal ini dapat terjadi karena penilaian konsumsi asupan kalori dengan metode food recall 24 jam mempunyai keterbatasan, dimana metode ini tidak dapat menggambarkan asupan kalori dalam jangka panjang. Jadi, bisa saja saat penelitian dilakukan anak mengonsumsi makanan cukup yang sesuai dengan AKG, namun diluar hari penelitian asupan kalori yang dikonsumsinya tidak cukup, begitu juga sebaliknya.

Persentase dari jenis makanan yang dikonsumsi harus sesuai dengan AKG, yaitu 50-70\% berasal dari karbohidrat, $15-30 \%$ dari lemak, $0,75 \mathrm{gr} / \mathrm{kgBB}$ atau sekitar $10-15 \%$ dari protein, selebihnya vitamin dan mineral. ${ }^{1}$ Dapat disimpulkan bahwa jumlah asupan kalori yang cukup yang sesuai dengan AKG, pemberian makanan yang bervariasi, serta diikuti dengan menerapkan cara pemberian makan yang benar pada anak akan menghasilkan status gizi yang baik.

\section{KESIMPULAN}

Terdapat hubungan yang signifikan antara pola makan dengan status gizi.

\section{DAFTAR PUSTAKA :}

1. Almatsier S. Prinsip dasar ilmu gizi. Jakarta: PT Gramedia Pustaka Utama; 2004.

2. Departemen Kesehatan RI. Riset kesehatan dasar 2013. Jakarta: Badan Litbangkes, Depkes RI; 2013.

3. Dinas Kesehatan Kota Padang. Profil kesehatan tahun 2012. Padang: Dinas Kesehatan Kota Padang; 2013.

4. Barness LA, John SC. Nutrisi: ilmu kesehatan anak Nelson Vol. 1 (terjemahan). Jakarta: EGC; 2000.

5. Kementerian Kesehatan. Kerangka kebijakan gerakan sadar gizi dalam rangka 1000 HPK. Jakarta: Kementerian Kesehatan RI; 2012.

6. Waladow G, Sarah MW, Julia VR. Hubungan pola makan dengan status gizi pada anak usia 3-5 
tahun di wilayah kerja Puskesmas Tompaso

Kecamatan Tompaso. Manado: Universitas Sam

Ratulangi Manado; 2012.
7. Manary JM, Noel WS. Aspek kesehatan masyarakat pada gizi kurang: gizi kesehatan masyarakat. Jakarta: EGC; 2008. 